\title{
FURTHER STEPS TOWARDS REUNION
}

W $E$ have always felt and expressed the opinion that the de facto separation between the Church of England and the Church of Rome came about by process of law; not, indeed, primarily ecclesiastical, but civil. In this it did but follow the character of our people, over whom the majesty of law has always had such sway that for a time the country accepted with almost Oriental fanaticism the Divine Right of Kings.

This fixed opinion of ours on the legal and civil origin of the breach with Rome led us to expect that the formal, official and collective separation would be ended by the same process which had been its cause. It became part of our service of Jesus Christ, the Truth, to look for any signs, however slender and struggling, of an official will or wish to have speech, if not yet inter-communion, with the Holy See. Perhaps our hopes gave sight to our eyes when we discerned in the official acts of the "Conference of Bishops of the Anglican Communion,' held at Lambeth in 1920 , some beginning of that official action by the Church of England which three centuries had awaited in vain.

It is to the credit of these prelates who, in 1920, foregathered at Lambeth from every continent of the world, that their words on re-union with Rome did not increase, but rather lessened, the difficulties of the situation. Combatants on both sides of the separation, too zealous to be wise, had added to the knots and intergrowth of an already complicated issue. Yet these zealots, whose zeal almost excused their unwisdom, might have taken heed of the splendid silences which the Church of Rome had offered in the service of the Truth. The same conscious sense of the weight of 


\section{Blackfriars}

official utterances guided the Lambeth Bishops to deal with the subject of reunion in a spirit which brought dawn, or the hope of dawn, a little nearer.

Let us set down the fateful official words of these 252 Bishops of the Anglican Communion:

'It is impossible to make any Report on Reunion with Episcopal Churches without some reference to Rome, even though it has no resolution to propose on the subject. We cannot do better than make our own the words of the Report of 1908 , which reminds us of

" the fact that there can be no fulfilment of the Divine purpose in any scheme of reunion which does not uitimately include the great Latin Church of the West, with which our history has been so closely associated in the past, and to which we are still bound by so many ties of common faith and tradition."

But we realize that-to continue the quotation-

" any advance in this direction is at present barred by difficulties which we have not ourselves created, and which we cannot of ourselves remove."

Should, however, the Church of Rome at any time desire to discuss conditions of reunion, we shall be ready to welcome such discussions.'

Although 'no resolution' was proposed, the relations between the Church of England and the Holy See were within the vision-field of Resolution Io, which ran as follows :

'The Conference recommends to the authorities of the Anglican Communion that they should, in such ways and at such times as they think best, formally invite the authorities of other Churches within their areas to confer with them concerning the possibility of taking definite steps to co-operate in a common endeavour on the lines set forth in the above Appeal to restore the unity of the Church of Christ.'

The vision of a re-united Christendom which the Lambeth Conference had interpreted to their flocks was soon followed by the zealous and unswerving efforts of those groups of Churchmen who felt sympathy with the non-episcopal Churches of the West and with the Orthodox Churches of the East. A little later the 428 


\section{Further Steps towards Reunion}

inevitable question of reunion with the Church of Rome was made a matter of prayer and effort by Churchmen with a keen sense of their close associations with it in the past, and of their stout bonds of common faith and tradition in the present. These zealous Churchmen, for whom Rome is still the Mother Church, have now found utterance and a spokesman under circumstances which allow us to add to the notquite-emptied cruse some further measures of hope. Let us describe the circumstances, the spokesman and the utterance.

On October 9th the annual Church Congress was opened at Sheffield. The English Church Union carried out its tradition by holding a meeting to express the desires and programme of that section of English Church which they represent. The subject of Reunion-abroad with Rome and Constantinople, at home with Modernism-was chosen for the deliberations of the meeting.

The spokesman chosen to deal with the subject of 'Reunion with Rome and the Holy See' was Lord Halifax. The choice could not have been wiser. The Church Times, in discussing the prospects of the meeting, commended the Union for its wisdom, saying: 'There is no man in the Church of England whose reputation stands higher than Lord Halifax.' We of "the other side' presume to endorse this opinion of those who know. We remember with gratitude that Lord Halifax, whose enthusiasm for reunion had so much to do with the preliminaries of the Apostolicae Curae, was almost alone in keeping this enthusiasm under circumstances that swamped the zeal of many of his fellow-Churchmen. His years and his infirmities now add a touch of tragedy to the words which the meeting of the English Church Union heard from his lips.

The utterance of this 'first gentleman' of the Church of England has been fitly epitomised by the 429 


\section{Blackfriars}

Church Times in the brief phrase: 'The whole question is now posed in a new light.' It is a matter of congratulation that the Church Times of October 6th, in summarising the points to be discussed by Lord Halifax, singled out those which we, too, had already judged to be the setting of an old difficulty in a new light. $^{2}$ The summary is of such importance that we must quote it at large :

' How far can and will the Church of England go in recognizing the Papacy? This does not mean the recognition of a bare primacy of honour; the Vatican decrees make it impossible for Rome to be contented with that. It means: Can any kind of a divine institution for the Papacy be allowed?

- Of course, if it be claimed that all power comes from Peter, and that the other bishops only derive what rights they have from him, then nothing can be done. The difference is insurmountable.

'But does Rome claim this? Not, it seems, in Cardinal Mercier's opinion . . . If Rome admits the divine rights of Bishops, can we admit that Peter was given by our Lord a position of superiority over the other Apostles? Lord Halifax thinks we can and ought. He says:-

"Can anyone read our Lord's separate charges to St. Peter, if controversy is put on one side, and regard paid to the general tradition of Christendom, without feeling that the natural inference to be drawn from them is that some special duty in regard to the whole Church was conferred upon him?"

'This will be startling reading to many Anglicans. No doubt some will think that the Church of England cannot possibly concede as much as this. It is likely, however, that there is a good deal of moderate opinion that will go a long way in this direction... There will be much sympathy with his attempt in modern circles. . . The whole question now poses in a new light.'

It is evident that the considered statement of the Church Times, almost more than the words of Lord

"Viscount Halifax's speech at the Sheffield meeting of the English Church Union is to be found in the published pamphlet, $A$ Call to Reunion (A. R. Mowbray).

${ }^{2}$ Church Times, 6 October, 1922 (editorial). 


\section{Further Steps towards Reunion}

Halifax, are a sign of this new light which, as the afterglow of the Lambeth Conference, has come upon the question of repairing the breach with Rome.

(I) There is a sense in which the Lambeth Conference is right in saying that the difficulties in the way of reunion with Rome are not the creation of the Church of England, but of the Crown of England. And assuredly these difficulties are not the creation of the Church of Rome. A recent writer, the Rev. A. H. Baverstock, ${ }^{3}$ speaking of the action of the Crown under Henry VIII, says :

- Force and fraud were now triumphant. The Church of England was wrested from all touch with the larger whole across the seas to whichi she belonged' (p. 16).

And all this without any action of Rome. During Henry VIII's reign Rome had not formulated any new doctrine, or claimed any new rights, to justify or excuse reprisals by the Church or Crown of England. Yet, as the result of a course of action initiated and carried through by the Crown, 'the Church of England was wrested' from Catholic unity.

(2) The same phenomenon took place on the coming of Elizabeth to the throne. Beginning with the second day of Queen Elizabeth's accession, there is a series of official Royal Acts which are registered in our official annals; yet Rome is silent. The Royal Acts are of almost daily occurrence from November 18th, 1538, when Archbishop Heath was asked to resign the seal, till October I 8th, I 559, when the bishops who had sought to preserve Catholic unity were committed to prison; yet Rome is silent. These Royal Acts include such Acts as :

(a) December 28th, 1558: Royal Proclamation forbidding anyone to preach or teach or change ceremonies until Parliament meet.

s Catholics and the Book of Common Prayer (The Catholic Literature Society). 


\section{Blackfriars}

(b) January, I559: Cecil sends to sheriffs a list of parliamentary candidates from whom to choose.

(c) February 29th, 1559: Commons pass Act of Supremacy.

(d) April 29th, 1559: House of Lords pass Act of Supremacy by three votes. N.B.-Five new Crown-peers had been created.

(e) October 3oth, I 559: Letters patent to Commissioners of Oath of Supremacy ordering them to administer it to ecclesiastics.

This is but the barest gleaning from the Royal Acts, which in less than a year had "wrested the Church of England' from Catholic unity; yet Rome is silent. There is not one official act of Rome towards England. Even the Papal Bull of Excommunication against Queen Elizabeth came ten years later, February 25th, 1570. And unless Elizabeth is recognised as the de jure Supreme Head of the Church of England, this excommunication of the Queen is not excommunication of the Church.

We set down these Royal Acts not as a denial of the Lambeth Bishops' plea that the difficulties in the way of reunion with Rome are not their creation; but as an eirenic effort to show that these difficulties can still less be called the creation of the Church of Rome.

(3) We are beyond measure glad that the divinely appointed mission and commission of St. Peter is now being stated, as it should be stated, in terms of the Episcopate. This new statement of the difficulty will lessen, and perhaps end, its pressure. Just as in reply to atheists we often say: 'We agreee with you. The being you call God does not exist. We do not believe or worship such a God'; so likewise we would say to conscientious upholders of the Episcopate and opponents of the Papacy, 'We agree with you. The Bishop whom you call Pope does not exist. We do 432 


\section{Further Steps towards Reunion}

not believe or obey such a Pope.' This is but to say what Lord Halifax and the Church Times have said, on the authority of Pope Leo XIII, that the Episcopate is of Divine, not Papal, institution. Let us set down the first-hand authorities for this true view of the Papacy, which may mean the end of many a misunderstanding :

Concilium Tridentinum (Sess. xxiii), A.D. ${ }^{56} 6_{3}$ Cap. IV. Sacrosancta Synodus declarat praeter caeteras Ecclesiasticas gradus, Episcopos, qui in Aposolorum locum successerunt, ad hunc hierarchicum Ordinem praecipue pertinere; et positos, sicut idem Apostolus ait, a Spiritu Sancto regere Ecclesiam Dei ; eosque Presbyteris superiores esse; ac Sacramentum Confirmationis conferre; ministros Ecclesiae ordinare.

Concilium Vaticanum (Sess. iv), A.D. 187 o. Cap. III. Tantum autem abest, ut haec Summi Pontificis potestas officiat ordinariae ac immediatae illi episcopalis jurisdictionis potestati, qua Episcopi, qui positi a Spiritu Sancto in Apostolorum locum successerunt, tamquam veri pastores assignatos sibi greges, singuli singulos, pascunt et regunt, ut eadem a supremo et universali Pastore asseratur, roboretur ac vindicetur.

Leo Papa XIII (Epist. Encyc. 'Satis Cognitum'). . . . sic Episcopi, quod succedunt Apostolis, horum potestatem ordinariam hereditate capiunt, ita ut intimam Ecclesiae constitutionem ordo episcoporum necessario attingat. Quamquam vero neque plenam neque universalem ii, neque summam obtinent auctoritatem, non tamen vicarii romanorum pontificum putandi .... .

Codex Juris Canonici. Can. 329, § I. Episcopi sunt Apostolorum successores atque ex divina institutione peculiaribus ecclesiis praeficiuntur quas cum potestate ordinaria regunt sub auctoritate Romani Pontificis.

Council of Trent (Sess. XxiII), A.D. 1563. The Holy Synod declares that more than the other Ecclesiastical Orders, bishops, who have taken the place of the apostles, belong especially to this hierarchical Order; and the same apostle says they are set by the Holy Spirit to rule the Church of God; they are the superior of priests; they confer the Sacrament of Confirmation, and they ordain the ministers of the Church. 


\section{Blackfriars}

Vatican Council (Sess. Iv). This power of the Sovereign Pontiff does no hurt to the ordinary and immediate power of episcopal jurisdiction whereby bishops, who being set by the Holy Spirit have taken the place of the apostles, feed and rule as true shepherds the several flocks assigned to them individually -indeed this (episcopal power) is asserted, strengthened, defended by the Sovereign and Universal Shepherd.

Pope Leo XIII (Satis Cognitum). Thus the Bishops, as succeeding to the apostles, receive as a legacy their (i.e. the apostles') ordinary power; so that the Body of Bishops belongs necessarily to the inmost constitution of the Church. Although they have received neither full, universal nor sovereign jurisdiction, nevertheless they are not to be accounted vicars of the Roman Pontiffs.

Code of Canon Law. Can. 329, §I. Bishops are successors of the apostles, and by divine institution they are set over individual churches, which they rule with ordinary power under the authority of the Roman Pontiff.

(4) As far as we know, this series of official decisions on the power of the episcopate is without parallel in the official acts of the Christian Churches. Certainly there is nothing equivalent in the official formulae of the post-Reformation Church of England.

It is therefore literally true that no Church in the world has so exalted the episcopate as the Church of Rome. This is all the more calculated to prove a peace-making fact, because of the circumstances which accompanied the Holy See's first official decision at the Council of Trent. Five years of Royal Supremacy, even when interpreted by the exigencies of a woman sovereign, had not tended to exalt the episcopate of the Church. Canterbury, York and their Suffragan 


\section{Further Steps towards Reunion}

Sees could remember only with regret the honour which had been theirs since their first creation by the Holy See. The bishops still in communion with the Holy See, when assembled at Trent in ${ }_{1} 5_{6} 3$ could hardly think of the dishonour shown to the episcopate by the English Crown without some word of protest. It is therefore to the honour of the Holy See that it made an infallible pronouncement that the bishops of the Catholic Church are, by the Word of Jesus, or by divine institution, the successors of the apostles. Never was the divine institution of the First Bishop more justified than in this effort to strengthen his brethren against the assaults of the Civil Power.

(5) The doctrine of the divine institution of the bishops, even when explained to mean that the bishops are not vicars of the Pope, may yet be hard of acceptance to some loyal Anglicans. They will urge that although the Catholic doctrine is Scriptural and authentic, the practice falls behind the doctrine. Doctrine defines that bishops are not the Pope's vicars; yet in practice each bishop is a Papal appointment.

The source of trouble in these loyal minds is the failure to distinguish between the appointment of the person and the granting of power. The Pope has for many centuries and for good reasons retained the appointment, or an effective veto on the appointment, of all bishops. But he has not claimed the right to limit the episcopal power, viz. of ruling and feeding the flock, of conferring the Sacraments of Order and Confirmation.

But the appointment of the bishops by a purely spiritual official might well be considered a spiritual necessity or privilege by those who have to submit, as the bishops of the provinces of Canterbury and York have to submit, to appointment by a purely civil official, the Prime Minister. Moreover, this appointment of the Archbishops and Bishops of the Church 


\section{Blackfriars}

of England by the civil authorities carries with it a control and limitation of the episcopal office which make the untrammelled action of the Roman Catholic episcopate 'the liberty of the sons of God.' To take an example from the recent case of St. Magnus, London, which was decided by the (lay) Chancellor of London. The rector of St. Magnus in a letter to the Church Times of August i ith, wrote :

- To-day we have an official of the Diocese of London solemnly ordering the immediate removal of the Russian Icon of our Lady and referring to the honour paid to it as superstitious. Eastern Orthodox will naturally be perplexed by this contradiction and pained by this insult.

'You will allow me this means of assuring them that to us these Faculty Courts have no spiritual authority . . . They have not only long ago been discredited by the most absurd and contradictory judgments, but are deprived of any shadow of claim to spiritual validity by their acknowledged subserviency to the purely civil Judicial Committee of the Privy Council.

'They are a gross invasion of the Bishop's rights of spiritual government, which it is amazing that any Bishop can tolerate. In this case, in which his own lay official implies the unlawfulness of Sacramental Confession, Reservation of the Blessed Sacrament, and of the due honour to our Lady, the Bishop of London writes that it would not be in order for him to criticize the decisions, and that he has no voice in them. The Orthodox, therefore ... will sympathise with his Lordship in the truly mortifying and humiliating position in which he is placed.'

We do not urge this point in any mood of controversy; but with a humble desire to show that the effort to recognise the divine institution of the episcopate crowned, strengthened and perfected by the divine institution of the Papacy, is calculated to restore the episcopate to its divine place.

God grant that the brave words of truth spoken by Lord Halifax amongst the hills of Yorkshire may begin a new Pilgrimage of Grace which may bring back England's lost unity in Jesus Christ!

$$
\text { Vincent McNabB, O.P. }
$$

